\title{
PERAN BANK SYARIAH MANDIRI (BSM) BAGI PEREKONOMIAN INDONESIA DI MASA PANDEMI COVID-19
}

\author{
Jefik Zulfikar Hafizd \\ Fakultas Syariah dan Ekonomi Islam \\ Institut Agama Islam Negeri Syekh Nurjati Cirebon \\ Email: hafizd.zulfikar@gmail.com
}

\begin{abstract}
Bank Syariah Mandiri (BSM) is one of the financial institutions with a major contribution to the Indonesian economy. The COVID-19 pandemic has affected various sectors, especially the economy. This literature study aims to determine the effects of a pandemic on the Indonesian economy, the impact of a pandemic on BSM, and the role of BSM in the economy during a pandemic. The results showed that the pandemic had an impact on the investment, trade, transportation, and tourism sectors. BSM intermediation activities have increased and have succeeded in generating profits. The pandemic has had a positive impact on BSM digital transactions, such as increasing the number of Mandiri Syariah Mobile users, increasing digital transactions, and increasing online account opening. The role of BSM during the pandemic includes restructuring customer financing, social assistance, maximizing CSR programs, implementing health protocols, and shifting bank activities to digital-based.
\end{abstract}

Keywords: BSM, The COVID-19 Pandemic, Economy, and Indonesia.

\begin{abstract}
Abstrak
Bank Syariah Mandiri (BSM) merupakan salah satu lembaga keuangan dengan kontribusi besar pada perekonomian Indonesia. Pandemi Coronavirus Disease-19 (COVID-19) menyebabkan berbagai sektor khususnya ekonomi terdampak. Studi pustaka ini bertujuan untuk mengetahui efek pandemi terhadap ekonomi Indonesia, dampak pandemi terhadap BSM, dan peran BSM bagi perekonomian di masa pandemi. Hasil penelitian menunjukkan bahwa pandemi berdampak pada sektor investasi, perdagangan, transportasi, dan pariwisata. Kegiatan intermediasi BSM mengalami peningkatan dan berhasil menghasilkan laba. Pandemi berdampak postif bagi transaksi digital BSM seperti peningkatan jumlah pengguna Mandiri Syariah Mobile, peningkatan transaksi digital, dan peningkatan pembukaan rekening online. Peran BSM di masa pandemi meliputi restrukturisasi pembiayaan nasabah, bantuan sosial, pemaksimalan program corporate social responsibility (CSR), penerapan protokol kesehatan, dan pengalihan kegiatan bank menjadi berbasis digital.
\end{abstract}

Kata Kunci: BSM, Pandemi COVID-19, Ekonomi, dan Indonesia. 


\section{PENDAHULUAN}

Pandemi COVID-19 memiliki dampak yang signifikan terhadap ekonomi dunia. Berbagai kebijakan diberlakukan guna mengatasi penyebaran COVID-19, seperti physical distancing, pemakaian masker hingga pembatasan sosial berskala besar (PSBB). Akibatnya terjadinya penurunan aktivitas manusia, para pelaku usaha khususnya pedagang kecil terpaksa berhenti berjualan sehingga mereka tidak memiliki pemasukan. Pandemi COVID-19 menyebabkan dampak luar biasa kepada ekonomi sehingga bisa menyebabkan peningkatan jumlah kemiskinan jika tidak ditanggulangi.

Masalah kemiskinan tidak hanya menjadi problem ekonomi, tetapi juga menjadi problem sosial dan politik. Problem ekonomi berdampak pada problem sosial, pendidikan, kesehatan dan politik. Problem inilah yang ini dihadapi oleh negara-negara berpenduduk muslim karena dapat membahayakan serta mengancam akidah, akhlak kelogisan berfikir, keluarga dan mengancam masyarakat muslim (Qardhawi, 2005). Kemiskinan bisa disebabkan oleh faktor internal dan faktor ekternal. Faktor internal disebabkan oleh manusia sendiri seperti rendahnya tingkat pendidikan, keterampilan, hingga budaya. Sedangkan faktor eksternal seperti rendahnya kemampuan mengakses sumber daya ekonomi, keterbatasan sarana prasarana umum hingga adanya bencana termasuk pandemi.

Pandemi merupakan tantangan nyata bagi dunia usaha, termasuk di dalamnya industri jasa keuangan perbankan. Bank Syariah sebagai lembaga intermediasi masyarakat yang memiliki dana dengan yang membutuhkan dana dituntut untuk dapat melakukan aktivitasnya ditengah ancaman paparan COVID-19. Perbankan Syariah memiliki peran strategis dalam pembangunan ekonomi Indonesia. Perbankan Syariah harus cepat beradaptasi dengan membuat strategi yang kreatif dan inovatif untuk bertahan dalam Pandemi COVID-19. Tantangan yang dihadapi perlu untuk diubah menjadi sebuah kesempatan menjadi lebih baik. Selain itu masa berakhirnya pandemi belum bisa diketahui.

Bank Syariah Mandiri (BSM) berperan hampir di semua sektor ekonomi masyarakat seperti konsumsi dan investasi. Di masa pandemi COVID-19, peran BSM sangat dibutuhkan untuk membantu sektor ekonomi yang tengah mengalami tekanan baik melalui restrukturisasi kredit nasabah maupun melalui penyaluran pembiayaan kredit baru. Sebagai bank syariah. BSM memiliki peran besar untuk memajukan ekonomi syariah, yakni ekonomi yang berbasis ajaran Islam untuk kemaslahatan umat manusia. Mengingat besarnya efek pandemi terhadap perekonomian dan pentingnya peran bank syariah di Indonesia maka penelitian terkait peran Bank Syariah Mandiri bagi perekonomian Indonesia di masa pandemi COVID-19 penting untuk dilakukan.

\section{LITERATURE REVIEW}

Penelitian mengenai dampak pandemi COVID-19 terhadap ekonomi pernah dilakukan oleh Sumarni pada tahun 2020. Penelitian yang bertema tentang "Pandemi COVID-19: Tantangan Ekonomi dan Bisnis" ini dilatarbelakangi oleh Pandemi COVID-19 yang melanda Indonesia dan menimbulkan dampak pada sektor ekonomi. Penelitian tersebut bertujuan untuk mengetahui dampak dari COVID-19 yang menjadi tantangan Ekonomi dan Bisnis Syariah di Indonesia dengan menggunakan pendekatan kualitatif. Hasil penelitian menunjukkan bahwa ekonomi dan bisnis syariah dapat memberikan kontribusi bagi masyarakat terdampak COVID-19 dengan mengedepankan tercapainya maqashid syariah (Sumarni, 2020).

Penelitian lain pernah dilakukan Albanjari dan Kurniawan tahun 2020 dengan tema "Implementasi Kebijakan Peraturan Otoritas Jasa Keuangan (POJK) No.11/POJK.03/2020 dalam menekan Non Performing Financing" dengan metode kualitatif naratif. Penelitian tersebut dilatarbelakangi oleh banyaknya aspek kehidupan yang dirugikan karena pandemi COVID-19 mulai dari bidang politik, sosial, 
budaya, keagamaan dan ekonomi. Tujuan penelitian tersebut adalah untuk mengetahui bagaimana Kebijakan POJK No.11/POJK.03/2020 dalam Menekan Non Performing Financing (NPF) di Bank Syariah. Hasil penelitian menunjukkan bahwa bank dapat menerapkan kebijakan yang mendukung pertumbuhan ekonomi nasabah pembiayaan bank syariah yang terdampak COVID-19 (Albanjari \& Kurniawan, 2020).

Hal serupa juga dibahas pada penelitian Ningsih dan Mahfudz tahun 2020 "Dampak Pandemi COVID-19 terhadap Manajemen Industri Perbankan Syariah: Analisis Komparatif" yang membandingkan 5 Bank Umum Syariah yakni Bank Syariah Mandiri, Bank Mega Syariah, Bank Syariah Bukopin, Bank Victoria Syariah dan Bank BJB Syariah. Penelitian tersebut dilatarbelakangi oleh banyaknya kasus terkonfirmasi COVID-19 di Indonesia yang berdampak pada ekonomi dan menjadi tantangan bagi bisnis Bank Syariah. Penelitian tersebut bertujuan untuk mengetahui dampak pandemi COVID-19 pada industri perbankan dari sisi manajemen strategi operasional bank dan kegiatan intermediasi bank. Hasil penelitian menunjukkan bahwa 5 bank syariah mengalami penurunan pada fungsi intermediasi. Pada manajemen strategi bank syariah menerapkan berbagai kebijakan seperti pembatasan layanan tatap muka langsung, kebijakan restrukturisasi kepada nasabah yang terdampak dan pemanfaatan aplikasi digital (Ningsih \& Mahfudz, 2020).

\section{METODE PENELITIAN}

Penelitian ini merupakan penelitian deskriptif kualitatif. Obyek Penelitian ini adalah Bank Syariah Mandiri (BSM) yang dipilih dengan pertimbangan sebagai salah satu lembaga jasa keuangan yang memberikan kontribusi besar pada perekonomian di Indonesia. Tujuan penelitian ini adalah untuk mengetahui efek pandemi terhadap ekonomi Indonesia, dampak pandemi terhadap bisnis Bank Syariah Mandiri dan peran Bank Syariah
Mandiri bagi perekonomian di masa pandemi. Peneliti menggunakan kajian studi pustaka guna mencari informasi melalui buku referensi, jurnal ilmiah, situs berita online, dan literatur lainnya yang relevan dengan tema penelitian untuk membentuk landasan teori.

\section{KONSEP DASAR \\ Pengertian Pandemi COVID-19}

Pandemi Coronavirus Disease-19 (COVID19) adalah penyakit atau wabah yang menyebar dari suatu wilayah ke beberapa negara dan mempengaruhi sejumlah besar orang di seluruh dunia termasuk Indonesia. Virus corona menyebar luas di dunia dengan cepat. Istilah pandemi tidak ada hubungannya dengan keganasan penyakit melainkan karena penyebarannya yang meluas.

Coronavirus adalah virus baru dan penyakit yang tidak diketahui sebelum mewabah di Wuhan, China pada Desember 2019. COVID-19 adalah singkatan dari CoronaVirus Disease-2019. WHO (Organisasi Kesehatan Dunia) secara resmi menyatakan virus corona (COVID-19) sebagai pandemi pada 9 Maret 2020 (WHO, 2020a). COVID-19 merupakan penyakit menular yang diakibatkan oleh jenis virus korona yang baru. Mayoritas orang yang terinfeksi COVID-19 mengalami penyakit pernapasan ringan hingga sedang serta bisa sembuh tanpa perlu perawatan khusus. Orang tua dan orang yang memiliki masalah kesehatan seperti penyakit kardiovaskular, diabetes, penyakit pernapasan kronis, dan kanker memiliki kemungkinan tinggi terjangkit penyakit serius. COVID-19 bisa menyebar melalui tetesan air liur atau cairan dari hidung ketika orang yang terinfeksi bersin atau batuk. Etika pernapasan di depan umum perlu dijaga dengan baik (WHO, 2020b).

\section{Pengertian Ekonomi}

Ekonomi adalah segala aktivitas yang dilakukan oleh manusia dalam usaha memenuhi kebutuhan dan keinginan. Ekonomi merupakan faktor penting bagi setiap manusia, Negara berhak mengatur 
kegiatan perekonomian untuk mencapai kesejahteraan yang adil bagi seluruh warga Negara Indonesia. Pengaturan ekonomi secara baik melalui peraturan perundangundangan dapat memberikan kemaslahatan yang besar bagi masyarakat. Stabilitas dan pertumbuhan ekonomi masyarkat bisa meningkatkan perekonomian Negara secara makro. Pertumbuhan ekonomi menjadi faktor yang mendukung pembangunan nasional.

Ekonomi berhubungan dengan kebutuhan dan keinginan. Kebutuhan adalah sesuatu yang harus diperoleh dan jika tidak terpenuhi akan menganggu fisik dan psikis manusia. Sedangkan keinginan adalah sesuatu yang bila tidak terpenuhi maka akan menggangu psikis tetapi tidak mengganggu fisik manusia (Karim, 2004). Kebutuhan merupakan hal yang diperlukan manusia baik benda atau pun jasa yang bisa memberikan kepuasan serta kemakmuran. Jika suatu kebutuhan manusia terpenuhi, maka akan muncul kebutuhan lainnya. Ketika belum memiliki rumah, seseorang berusaha untuk memiliki rumah, kemudian muncul kebutuhan dan keinginan baru seperti menginginkan isi rumah, kemudian menginginkan mobil, villa, dan sebagainya (Zainur, 2020). Kebutuhan yang harus dipenuhi guna menjaga kelangsungan hidup disebut kebutuhan primer sedangkan keinginan yang merupakan hal yang disenangi atau ingin dimiliki bisa disebut kebutuhan sekunder dan tersier. Kebutuhan tersier merupakan kebutuhan akan kemewahan.

Permasalahan ekonomi adalah adanya keterbatasan alat pemuas kebutuhan dan keinginan. Dengan adanya keterbatasan tersebut, manusia dituntut untuk berusaha secara maksimal agar bisa memperoleh apa yang dibutuhkan atau diinginkan.

\section{Pengertian Bank Syariah}

Bank berasal dari bahasa Itali, "Banca" yang memiliki arti meja yang digunakan para penukar uang di pasar. Pada dasarnya bank adalah tempat penitipan atau penyimpanan uang, pemberi atau penyalur kredit dan perantara pembayaran (Hrp \& Saraswati, 2020). Pada Undang-Undang No. 10 Tahun 1998 tentang Perbankan dijelaskan bahwa bank adalah badan usaha yang menghimpun dana dari masyarakat dalam bentuk simpanan dan menyalurkannya kepada masyarakat dalam bentuk kredit dan atau bentuk-bentuk lainnya dalam rangka meningkatkan taraf hidup rakyat banyak (Presiden \& Mensesneg, 1998). Secara sederhana bank dapat disebut sebagai lembaga penyimpanan uang dan penyaluran kredit masyarakat. Pada perkembangannya bank terbagi menjadi dua, yakni bank konvensional dan bank syariah.

Bank Syariah adalah Bank yang menjalankan kegiatan usahanya berdasarkan Prinsip Syariah dan menurut jenisnya terdiri atas Bank Umum Syariah dan Bank Pembiayaan Rakyat Syariah (DPR \& Presiden, 2008). Bank syariah adalah bank yang melaksanakan kegiatan usaha berdasarkan prinsip Syariah, yaitu aturan perjanjian berdasarkan hukum Islam antara bank dan pihak lain untuk penyimpanan dana dan atau pembiayaan kegiatan usaha, atau kegiatan lainnya yang dinyatakan sesuai dengan Syariah (Yumanita, Pendidikan, Studi, \& Ppsk, 2005). Bank syariah beroperasi dengan landasan bagi hasil, ditambah dengan jual beli dan sewa. Bank Syariah berorientasi pada kesejahteraan sosial sebagaimana tujuan ekonomi syariah. Bank syariah atau Perbankan syariah memiliki kelembagaan yang terbagi menjadi Bank Umum Syariah (BUS), Unit Usaha Syariah (UUS), dan Bank Perkreditan Rakyat Syariah (BPR syariah). Kegiatan perbankan syariah berhubungan dengan kelembaggan lain di luar bank, yakni Dewan Syariah Nasional (DSN), Dewan Pengawas Syariah (DPS), Badan Arbitrase Syariah Nasional (BASYARNAS), Bank Indonesia (BI), dan Otoritas Jasa Keuangan (OJK).

Dewan Syariah Nasional (DSN) Majelis Ulama Indonesia (MUI) memiliki peran penting dalam menjamin pemenuhan kepatuhan syariah yang diatur dalam sistem dan mekanisme bank syariah. Undangundang No. 21 Tahun 2008 tentang Perbankan Syariah memberikan MUI 
kewenangan untuk menerbitkan fatwa mengenai kesesuaian suatu kegiatan atau produk perbankan dengan syariah. Secara khusus fatwa tersebut dikaji dan dikeluarkan oleh DSN-MUI. Kemudian Peraturan Bank Indonesia (sekarang POJK) menegaskan bahwa seluruh produk perbankan syariah hanya bisa ditawarkan kepada masyarakat setelah bank mendapat fatwa dari DSN-MUI serta mendapatkan ijin dari OJK. Bank syariah wajib memiliki Dewan Pengawas Syariah (DPS) dalam rangka mengatur dan mengawasi kegiatan operasional bank, DPS memiliki dua fungsi yakni: pertama fungsi pengawasan syariah dan kedua fungsi advisory (penasehat) ketika bank dihadapkan pada pertanyaan mengenai apakah suatu kegiatan sesuai syariah atau tidak, serta dalam rangka pengembangan produk yang kemudian disampaikan kepada DSN untuk ditetapkan fatwanya. Selain fungsi tersebut, perbankan syariah memiliki fungsi internal audit yang membantu DPS untuk fokus pada pemantauan kepatuhan syariah. Audit eksternal bank syariah dilakukan oleh auditor yang memiliki kualifikasi dan kompetensi di bidang syariah (OJK, 2017).

Bank Syariah merupakan lembaga intermediasi sekaligus penyedia layanan jasa keuangan yang dijalankan berlandaskan etika dan sistem nilai Islam, khususnya terbebas dari bunga (riba), bebas dari kegiatan spekulatif yang tidak produktif seperti perjudian (maysir), bebas dari hal-hal yang tidak jelas serta meragukan (gharar), menjunjung keadilan, dan hanya membiayai kegiatan usaha yang halal (Yumanita et al., 2005). Bank syariah merupakan tempat intermediasi antara pihak pemilik dana dan pihak yang membutuhkan dana. Perbedaan bank syariah dengan bank konvensional adalah pada dasar pencarian keuntungan bank, bank syariah menerapkan prinsip bagi hasil atas pembiayaan sedangkan bank konvensional menggunakan bunga atas pokok utang. Bunga berupa tambahan atas pokok hutang tidak diperbolehkan karena mengandung sifat riba yang dilarang oleh Islam.
Perbankan Syariah bertujuan menunjang pelaksanaan pembangunan nasional dalam rangka meningkatkan keadilan, kebersamaan, dan pemerataan kesejahteraan rakyat (DPR \& Presiden, 2008). Fungsi Bank Syariah dalam paradigma Islam antara lain manajemen investasi, investasi, jasa keuangan, dan jasa sosial (Antonio, 2001). Manfaat yang paling butuhkan nasabah dari suatu perbankan adalah kenyamanan yang diberikan, baik dari segi kemudahan maupun segi keamanan (Fatimah \& Hendratmi, 2020). Bank Syariah bisa menginvestasikan dana pada sektor usaha dengan menggunakan instrumen investasi yang sesuai dengan syariah. Bank Syariah bisa menawarkan berbagai jasa keuangan berdasarkan upah (fee based) dalam suatu kontrak perwakilan atau penyewaan. Bank Syariah juga perlu melaksanakan jasa atau kegiatan sosial dalam rangka pemerataan kesejahteraan rakyat.

\section{PEMBAHASAN DAN DISKUSI}

\section{Efek Pandemi terhadap Perekonomian Indonesia}

Pandemi COVID-19 berdampak pada perekonomian global termasuk Indonesia yang mengalami penurunan drastis. Banyak UMKM (Usaha, Mikro, Kecil dan Menengah) hingga Perusahaan Besar mengalami kerugian. Akibatnya banyak tenaga kerja mendapat PHK (Pemutusan Hubungan Kerja) karena perusahaan tidak sanggup membayar gaji karyawannya. Gelombang PHK menyebabkan jumlah pengangguran meningkat hingga lebih dari 2,3 juta orang. Dampak ekonomi diperkirakan akan sangat parah, menurunkan tingkat pertumbuhan ekonomi yang diproyeksikan untuk tahun 2020 dari sekitar $5 \%$ turun menjadi $-5 \%$. Angka kemiskinan akan meningkat dari 9,2\% pada September 2019 menjadi 9,7\% pada akhir tahun 2020, mendorong 1,3 juta lebih banyak orang ke dalam kemiskinan. Jika tingkat kemiskinan bertambah maka masyarakat bisa mengalami kesulitan memenuhi kebutuhan primer.

Pandemi COVID-19 menyebabkan rendahnya sentimen investor pada pasar 
Indonesia, hal ini membawa pasar ke arah cenderung negatif. Keputusan strategis terkait fiskal dan moneter sangat diperlukan untuk memberikan stimulus ekonomi (Aditia et al., 2020). Kebijakan fiskal merupakan kebijakan yang mengatur pengeluaran dan pendapatan pemerintah. Kebijakan moneter, merupakan kebijakan yang bertujuan menjaga stabilitas ekonomi dengan cara mengontrol tingkat bunga perbankan serta jumlah uang beredar. Langkah strategis sangat diperlukan mengingat banyak sektor ekonomi terdampak pandemi.

Sektor usaha yang paling jelas terkena pandemi adalah sektor investasi, perdagangan, transportasi, dan pariwisata. Di bidang perdagangan, Indonesia mengalami penurunan penerimaan pajak sektor perdagangan. Pajak sektor perdagangan merupakan sumber terbesar kedua setelah industri pengolahan. Penurunan pajak juga terjadi pada ekspor migas dan non-migas. Tiongkok yang merupakan importir minyak mentah terbesar mengurangi kegiatan impor selama pandemi COVID-19 (BPS, 2020). Di bidang investasi, proyeksi pasar Indonesia mengalami penundaan investasi karena rantai pasokan yang tidak jelas dan perubahan asumsi pasar. Investasi di Indonesia banyak dilakukan oleh sektor swasta termasuk dari luar negeri. Pandemi COVID-19 juga berdampak pada maskapai angkutan udara Indonesia. Akibat pemberlakuan pembatasan perjalanan ke luar negeri, banyak maskapai penerbangan yang membatalkan penerbangan, sedangkan maskapai yang tetap beroperasi juga mengalami kerugian karena mayoritas kursi pesawatnya kosong, bahkan perusahaan penerbangan raksasa sekelas Garuda Indonesia terpaksa harus melakukan pemutusan hubungan kerja kepada labih dari 700 orang pegawai. Di sektor pariwisata terjadi penurunan jumlah turis yang berdampak pada penurunan pendapatan di sektor penunjang pariwisata seperti hotel, restoran, dan pedagang kaki lima. Hunian hotel mengalami penurunan hingga $4 \%$ dengan daerah yang sangat terpengaruh adalah Bali, Manado, Kepulauan Riau,
Bangka Belitung, Medan, dan Jakarta. Begitu pula dengan Usaha Mikro Kecil dan Menengah (UMKM) yang berada di sekitar kawasan pariwisata mengalami penurunan omzet akibat berkurangnya jumlah wisatawan, terutama UMKM yang menyediakan produk untuk oleh-oleh, catering, jajanan, dan sejenisnya.

Pandemi berdampak terhadap aktivitas bisnis Perbankan Syariah. Dampak yang dirasakan oleh bank syariah meliputi: Pertama, kewajiban menjalankan secara maksimal protokol kesehatan. Kedua, bank syariah harus memberikan keringanan kepada debitur untuk menunda pembayaran sebagaimana diatur oleh PJOK Nomor 11/POJK.03/2020. Adanya protokol kesehatan tentu bisa menghambat kegiatan bisnis bank syariah namun demi tujuan kemanusiaan melalui menjaga kesehatan maka hal tersebut perlu dilaksanakan. Penggunaan layanan digital bisa menjadi salah satu solusi atas pembatasan aktivitas sosial. Kemudian pemberian keringanan pembayaran pembiayaan di bank merupakan upaya penyelamatan UMKM dari kebangkrutan. Apabila banyak usaha mengalami kebangkrutan maka ekonomi Indonesia akan terus menurun.

Pemerintah Republik Indonesia sebagai regulator mengeluarkan berbagai kebijakan untuk menstimulus dampak Covid-19 terhadap perekonomi Indonesia, termasuk di sektor industri perbankan. Pemerintah melalui Otoritas Jasa Keuangan (OJK) menetapkan Peraturan Otoritas Jasa Keuangan Nomor 11/POJK.03/2020 tentang Stimulus Perekonomian Nasional Sebagai Kebijakan Countercyclical Dampak Penyebaran Corona Virus Disease 2019 (OJK, 2020). Kebijakan tersebut memberikan kelonggaran kredit usaha mikro dan usaha kecil yang mencakup kebijakan penilaian kualitas pembiayaan hanya didasarkan pada ketepatan pembayaran pokok dan margin/ bagi hasil/ ujrah untuk pembiayaan di bawah 10 Miliar Rupiah dan Skema Restrukturisasi pembiayaan. Mekanisme setiap utang atau pembiayaan direstrukturisasi oleh pihak bank atau perusahaan, pembiayaan dapat 
ditetapkan menjadi lancar apabila debitur teridentifikasi terdampak Pandemi COVID19. Debitur yang mendapatkan perlakuan khusus dalam POJK tersebut adalah yang mengalami kesulitan memenuhi kewajiban pada Bank karena terkena dampak dari wabah virus COVID-19. Kebijakan bank syariah yaitu memberikan relaksasi kepada nasabah terhadap fasilitas pembiayaan seperti melalui penundaan pembayaran serta pemberian keringanan margin (bagi hasil) yang kurun waktu dan syaratnya disesuaikan dengan sektor ekonomi, kriteria, dan kondisi nasabah dengan mengacu pada POJK.

Bank Indonesia menurunkan BI 7-Day Reverse Repo Rate (BI7DRR) sejumlah 25 bps menjadi 4,75\%, suku bunga Deposit Facility sejumlah 25 bps menjadi $4,00 \%$, dan suku bunga Lending Facility sejumlah 25 bps menjadi 5,50\%. Kebijakan moneter dibuat secara akomodatif dengan kondisi dan konsisten terhadap prakiraan inflasi, stabilitas eksternal aman, serta sebagai langkah pre-emptive dalam rangka menjaga momentum pertumbuhan ekonomi domestik. Bank Indonesia menyesuaikan ketentuan perhitungan Rasio Intermediasi Makroprudensial (RIM) dengan menambah cakupan pendanaan serta pembiayaan terhadap kantor cabang bank. Strategi operasi moneter ditetapkan guna menjaga likuiditas dan mendukung adanya transmisi bauran kebijakan. Kebijakan makroprudensial mampu meningkatkan pembiayaan ekonomi sebagaimana siklus keuangan yang masih di berada bawah optimal dengan tetap menjaga prinsip kehatihatian. Pertumbuhan ekonomi diperkuat melalui kebijakan sistem pembayaran yakni melalui perluasan akseptasi QRIS (Quick Response Code Indonesian Standard) dan elektronifikasi bantuan sosial dan transaksi keuangan Pemerintah Daerah. (Bank Indonesia, 2020).

Bank Syariah dalam menjalankan fungsinya sebagai lembaga intermediasi atau perantara keuangan yang mempertemukan antara masyarakat yang kelebihan dana dengan masyarakat yang kekurangan dana dituntut untuk dapat berinteraksi dengan orang banyak. Namun disisi lain, ancaman terhadap paparan virus Covid-19 menjadi tantangan bagi lembaga perbankan. Berbagai kebijakan dikeluarkan perbankan untuk tetap dapat bertahan ditengah pandemi COVID-19 (Ningsih \& Mahfudz, 2020). Industri perbankan syariah perlu menyusun strategi baru yang relevan dengan kondisi pandemi COVID-19. Peluang selalu menyertai tantangan sebagaimana tantangan yang disebabkan pandemi perlu dimanfaatkan dengan baik. Tantangan pertama, industri perbankan syariah harus merubah pola bisnis menjadi layanan bank berbasis digital pada sisi penghimpunan dana dan pembiayaan. Kedua, mengurangi pembayaran Non Performing Finanacing (NPF). Ketiga, mencari alternatif pasar baru, khususnya pasar yang tidak terdampak signifikan dari sisi ekonomi oleh pandemi COVID-19 (Tahliani, 2020).

\section{Analisis Dampak Pandemi terhadap Bisnis Bank Syariah Mandiri}

PT Bank Syariah Mandiri merupakan lembaga keuangan yang terdaftar dan diawasi oleh Otoritas Jasa Keuangan. Bank Syariah Mandiri (BSM) merupakan bank yang memadukan semangat idealisme bisnis dengan nilai spiritual di dalam kegiatan operasionalnya. BSM memiliki 1 Kantor Pusat serta 1.736 jaringan 129 kantor cabang, 398 kantor cabang pembantu, 50 kantor kas, 1000 layanan syariah bank di Bank Mandiri dan jaringan kantor lainnya, 114 payment point, 36 kantor layanan gadai, 6 kantor mikro dan 3 kantor non operasional di seluruh propinsi di Indonesia, dengan akses lebih dari 200.000 jaringan ATM (BSM, 2017).

BSM memiliki Visi menjadi Bank Syariah terdepan dan modern. BSM memberikan pesan kepada nasabah bahwa BSM merupakan bank pilihan yang memberikan manfaat, menenteramkan dan memakmurkan. Bagi pegawai, BSM merupakan bank yang menyediakan kesempatan untuk beramanah sekaligus berkarir profesional. Untuk Investor, BSM merupakan institusi keuangan syariah Indonesia yang terpercaya yang terus 
memberikan value berkesinambungan. Adapun Misi BSM yakni: 1) Mewujudkan pertumbuhan dan keuntungan di atas ratarata industri yang berkesinambungan; 2) Meningkatkan kualitas produk dan layanan berbasis teknologi yang melampaui harapan nasabah; 3) Mengutamakan penghimpunan dana murah dan penyaluran pembiayaan pada segmen ritel; 4) Mengembangkan bisnis atas dasar nilai-nilai syariah universal; 5) Mengembangkan manajemen talenta dan lingkungan kerja yang sehat; dan 6) Meningkatkan kepedulian terhadap masyarakat dan lingkungan (BSM, 2017).

Untuk mewujudkan Visi dan Misi BSM, insan-insan BSM perlu memiliki dan menerapkan keseragaman nilai yang sejalan visi dan misi. Nilai-nilai yang digali dan disepakati kemudian disebut BSM Shared Values yakni AKHLAK (Amanah, Kompeten, Harmonis, Loyal, Adaptif, Kolaboratif). Amanah memiliki makna memegang teguh kepercayaan yang diberikan. Kompeten artinya cakap, terus belajar dan mengembangkan kapabilitas. Harmonis berarti keserasian, saling peduli dan menghargai perbedaan. Loyal berarti berdedikasi dan mengutamakan kepentingan bangsa dan Negara. Adaptif berarti terus berinovasi dan antusias dalam menggerakkan ataupun menghadapi perubahan. Kolaboratif berarti membangun kerja sama yang sinergis (BSM, 2017).

Bank Syariah Mandiri didukung penuh oleh Bank Mandiri sebagai Pemegang Saham Pengendali dan para pemegang saham lain. Kecukupan modal minimum bank perlu dipenuhi dalam rangka menjaga kelangsungan fungsi lembaga intermediasi. Penguatan permodalan akan dipenuhi dari retained earning setiap tahun yang berasal dari tambahan setoran modal Bank Mandiri serta melalui corporate action atau sumber permodalan lain seperti penerbitan sukuk dan strategic partner atau investor dan atau IPO (BSM, 2019). Peningkatan jumlah nasabah harus diimbangi dengan peningkatan pelayanan. Peningkatan pelayanan yang dapat dilakukan adalah dengan terus meningkatkan kehandalan teknologi informasi dalam setiap layanan dan produkproduk perbankan, penerapan teknologi informasi terkini serta melakukan inovasiinovasi secara berkesinambungan untuk meningkatkan daya saing dalam industri perbankan. Selain itu, PT Bank Syariah Mandiri fokus pada strategi peningkatan produktivitas, kapabilitas dengan memperkuat fungsi Mandiri Syariah University untuk menjadikan pegawai Mandiri Syariah sebagai Bankir Syariah yang unggul dan kompeten. Fokus strategi lainnya adalah memperkuat penerapan budaya risk, budaya digital, budaya sales dan mengimplementasikan employee value proposition yang membedakan dengan Bank Syariah ataupun bank lainnya (BSM, 2019).

Dampak pada Manajemen Strategi Bank Syariah Mandiri. Bank Mandiri Syariah selama pandemi Covid-19 mengeluarkan kebijakan terkait dengan produk dan layanan sebagai berikut: Pertama, Mandiri Syariah Mobile (MSM). Mandiri Syariah Mobile disebut sebagai Superaps, yang mana satu aplikasi tidak hanya dapat melakukan transaksi keuangan tetapi juga menawarkan berbagi fitur-fitur tambahan diantaranya seperti fitur pembayaran zakat, sedekah, wakaf, serta ibadah melalui kemudahan mendapatkan jadwal sholat, arah kiblat, lokasi masjid, juz amma, kutipan hadits, dan lain-lain. Mandiri Syariah Mobile (MSM) dapat pula untuk transaksi e-commerce, pembayaran haji, top-up e-wallet (emoney, gopay, ovo). Kedua, QRIS. Transaksi menggunakan smartphone. Quick Response Code Indonesia Standard (QRIS) memudahkan dengan gadget dan teknologi untuk melakukan transaksi melalui metode pembayaran digital QRIS. Ketiga, Kebijakan Stimulus Perekonomian Nasional No.11/ POJK.03/ 2020. Bank melonggarkan fasilitas pembiayaan kepada nasabah yang terdampak pandemi Covid-19 dalam bentuk penundaan pembayaran dan atau penurunan margin atau bagi hasil untuk jangka waktu tertentu dan persyaratannya disesuaikan dengan sektor ekonomi, kriteria, dan kondisi nasabah dengan tetap mengacu pada ketentuan OJK 
untuk nasabah terutama UKM (Ningsih \& Mahfudz, 2020).

Pandemi menyebabkan beberapa risiko yang dihadapai perbankan syariah, antara lain risiko pembiayaan, risiko operasional dan risiko pasar. Risiko pembiayaan bisa timbul akibat kegagalan nasabah dalam memenuhi kewajiban mengingat tidak sedikit nasabah yang kehilangan pekerjaan dan mengalami penurunan pendapatan. Risiko operasional diakibatkan perlambatan operasional seperti pembatasan nasabah yang datang ke bank, pemotongan jam operasional, work from home, bahkan hingga penutupan cabang bank syariah di beberapa daerah untuk sementara waktu. Risiko pasar tidak menjadi masalah besar bagi bank syariah karena bank syariah menerapkan sistem bagi hasil bukan sistem bunga.

Pandemi COVID-19 berdampak kepada manajemen strategi operasional perbankan. BSM menerapkan stimulus ekonomi terkait pembiayaan restrukturisasi untuk Nasabah yang terkena dampak pandemi COVID-19 berdasarkan POJK No.11/ POJK.03/ 2020. Pengembangan aplikasi digital mobile banking pada dilakukan secara lebih serius mengingat adanya pembatasan aktivitas sosial yang perlahan dialihkan menjadi aktivitas daring. Transaksi BSM dialihkan dari transaksi di cabang menjadi transaksi digital, sehingga transaksi Mandiri Syariah Mobile dan Internet Banking Mandiri Syariah meningkat signifikan.

Pandemi membawa dampak positif terhadap perkembangan transaksi digital. Hal ini dapat terlihat dari peningkatan jumlah User MSM (Mandiri Syariah Mobile) yang mengalami peningkatan hingga 45 persen dari 860 ribu nasabah pada juni 2019 menjadi 1,25 juta nasabah pada juni 2020. Jumlah transaksi digital per bulan mengalami peningkatan 113,4 persen dari 1,7 juta transaksi pada juni 2019 menjadi 3,6 juta transaksi pada juni 2020. Jumlah pembukaan rekening secara online mengalami peningkatan dari 5.348 rekening pada januari 2020 menjadi 61.318 rekening pada juni
2020. Fee based income (FBI) layanan digital mengalami kenaikan hingga 35,83\%, dari Rp107,87 miliar per Juni 2019 menjadi Rp146,52 miliar pada Juni 2020. Kontribusi fee based income (FBI) layanan digital paling besar berasal dari mobile banking yang meningkat $65,38 \%$ YoY dari Rp17,29 miliar per Juni 2019 menjadi Rp28,60 miliar pada Juni 2020 (BSM, 2020).

Dampak pandemi pada kegiatan intermediasi BSM dapat dilihat dari perkembangan pembiayaan dan dana pihak ketiga (DPK). Pembiayaan BSM mengalami peningkatan hingga akhir Juni 2020 sejumlah Rp75,61 triliun, meningkat 5,8\% dari Juni 2019 yang sebesar Rp71,47 triliun. DPK pada Juni 2020 sebesar Rp101,78 triliun, mengalami peningkatan $16,52 \%$ dari Rp87,36 triliun per Juni 2019. Berdasarkan total dana tersebut, porsi low cost fund mencapai 57,93\%. Pertumbuhan DPK mampu menambah aset Mandiri Syariah pada Juni 2020 hingga Rp114,40 triliun atau naik 13,26 persen dari Juni 2019 yang sebesar Rp101,01 triliun. Pencapaian yang diperoleh memperkuat posisi BSM sebagai bank syariah terbesar di Indonesia. Kualitas pembiayaan menjadi tantangan di masa pandemi. BSM mempertebal cadangan likuiditas yang berdampak pada penurunan angka non performing financing (NPF) Net dari 1,21\% per Juni 2019 menjadi $0,88 \%$ per Juni 2020. Sedangkan, NPF Gross turun dari 2,89\% di Juni 2019 menjadi 2,57 \% per Juni 2020 (BSM, 2020).

Laba bersih BSM berhasil diperoleh dari keberhasilan dalam peningkatan pembiayaan dan penghimpunan dana pihak ketiga (DPK). Keberhasilan tersebut mendorong peningkatkan aset dan komposisi low cost fund dan keberhasilan BSM menurunkan angka non performing financing (NPF) diperoleh melalui apenyaluran pembiayaan secara selektif dan berkualitas. BSM berhasil membukukan laba bersih sebesar Rp719 miliar per Juni 2020 naik signifikan $30,53 \%$ dibanding tahun sebelumnya. Kenaikan laba ditopang oleh pendapatan margin dan FBI yang berasal dari layanan digital. 
Peran Bank Syariah Mandiri bagi Perekonomian Indonesia

Permasalahan ekonomi yang dihadapi masyarakat Indonesia akibat dampak pandemi dapat diselesaikan dengan beberapa solusi seperti: (1) penyaluran bantuan langsung tunai yang berasal dari zakat, infak dan sedekah; (2) penguatan wakaf baik berupa wakaf uang, wakaf produktif, waqf linked sukuk maupun wakaf untuk infrastruktur; (3) bantuan modal usaha untuk UMKM terdampak pandemi; (4) skema qardhul hasan; (5) peningkatan literasi ekonomi dan keuangan syariah; (6) melalui pengembangan teknologi finansial syariah (Iskandar, Possumah, \& Aqbar, 2020). Dalam rangka melakukan Corporate Social Responsibility BSM bekerjasama dengan kerjasama Lembaga Amil Zakat Nasional Bangun Sejahtera Mitra Umat (LAZNAS BSM) yang dibangun oleh Yayasan Bangun Sejahtera Mitra Umat (BSM Umat). Dalam menjalankan aktivitasnya, LAZNAS BSM memiliki tiga program unggulan yakni: Program Mitra Umat, Program Didik Umat serta Program Simpati Umat (Irawan, 2020).

BSM memiliki peran signifikan dalam perekonomian Indonesia di masa pandemi COVID-19. BSM memberikan bantuan kepada masyarakat dan umat melalui penyaluran beberapa bantuan Covid-19 diantaranya 1) Restrukturisasi pembiayaan kepada lebih dari 29.000 nasabah senilai Rp7,1 Triliun; 2) Pembagian 2.500 alat pelindung diri (APD) dan 100.000 masker ke 105 rumah sakit rujukan COVID-19; 3) Pembagian 3 ton beras untuk panti asuhan; 4) Pembagian 26.600 paket bahan pangan; dan 5) Pembagian 18.000 masker untuk pondok pesantren (BSM, 2020). Selain itu BSM memiliki banyak kontribusi melalui program corporate social responsibility seperti pembangunan masjid, pembagian hewan Qurban, pembagian al-Qur'an, memberdayakan ekonomi desa binaan, bantuan perbaikan sekolah, bmodal usaha, dan program lainnya.

Dalam upaya mengatasi penyebaran COVID-19, BSM memiliki komitmen untuk menjaga protokol kesehatan bagi nasabah dan pegawai. Dari sisi ekonomi, BSM gencar mengimbau nasabah untuk beralih ke transaksi digital. Transaksi digital memiliki beberapa kelebihan antara lain bisa dilakukan di mana saja secara daring, lebih praktis karena tidak harus datang ke bank atau ATM untuk transfer, dan meminimalisasi kontak dengan orang lain ketika bertransaksi.

\section{KESIMPULAN}

Berdasarkan hasil studi dapat disimpulkan bahwa pandemi COVID-19 berdampak pada sektor ekonomi yang tercermin dari penurunan pertumbuhan ekonomi dan bisnis khususnya sektor investasi, perdagangan, transportasi, dan pariwisata. Kegiatan intermediasi Bank Syariah Mandiri mengalami peningkatan positif dan berhasil menyumbangkan laba. Peran Bank Syariah Mandiri terhadap ekonomi di masa pandemi meliputi restrukturisasi pembiayaan nasabah yang terdampak pandemi COVID-19, pembagian bantuan sosial, pemaksimalan program corporate social responsibility (CSR), menjaga protokol kesehatan dan pengalihan kegiatan bank menjadi berbasis digital.

Pandemi COVID-19 merupakan ujian sekaligus momentum bagi umat Islam untuk mengaktualisasikan nilai dan pesan agama dengan mengoptimalkan peran Ekonomi Syariah. Adanya Bank Syariah dapat menjadi instrumen powerful dan memiliki peran fundamental untuk mengatasi efek pandemi dengan program nyata yang membantu dan memberdayakan masyarakat.

\section{DAFTAR PUSTAKA}

Aditia, D., Nasution, D., Sains, F. S., Pembangunan, U., Budi, P., \& Utara, U. S. (2020). Dampak Pandemi COVID-19 Terhadap Perekonomian. Jurnal Benefita, 5(2), 212-224.

Albanjari, F. R., \& Kurniawan, C. (2020). Implementasi Kebijakan Peraturan Otoritas Jasa Keuangan (POJK) No.11/POJK.03/2020 Dalam Menekan Non Performing Financing (NPF) Pada Perbankan Syariah. Jurnal Eksyar (Jurnal Ekonomi Syariah), 7(1), 24-36.

Antonio, M. S. (2001). Bank Syariah Dari Teori 
ke Praktik. Jakarta: Gema Insani Press.

Bank Indonesia. (2020). BI 7-Day Reverse Repo Rate Turun 25 bps Menjadi 4,75\%: Memperkuat Stabilitas, Mendorong Momentum Pertumbuhan. Retrieved from https://www.bi.go.id/id/ruangmedia/siaran-pers/Pages/SP_221320.aspx

BPS. (2020). Perkembangan Ekspor dan Impor Indonesia Januari 2020. Berita Resmi Statistik, (55), 1-16. Retrieved from https://www.bps.go.id/pressrelease/downlo ad.html?nrbvfeve=MTY3NQ\%3D\%3D\&s $\mathrm{dfs}=$ ldjfdifsdjkfahi\& twoadfnoarfeauf $=\mathrm{MjA}$ yMC0wOS0wNiAyMzozMjoyOA\%3D\%3 $\mathrm{D}$

BSM. (2017). Home|Bank Mandiri Syariah. Retrieved from PT Bank Syariah Mandiri website: https://www.mandirisyariah.co.id/ BSM. (2019). Laporan Tahunan 2019: Memberikan Nilai Tambah Melalui Pengembangan Kapabilitas Internal. Jakarta.

BSM. (2020). Cetak Laba 719 M, Mandiri Syariah Bukukan Kinerja Solid Sepanjang Semester I 2020. Retrieved October 20, 2020, from PT Bank Syariah Mandiri website:

https://www.mandirisyariah.co.id/newsupdate/cetak-laba-719-m-mandiri-syariahbukukan-kinerja-solid-sepanjang-semesteri-2020-\#: :text=Pertumbuhan DPK tersebut juga mendorong,yang sebesar Rp101\%2C01 triliun.\&text=Dari sisi pembiayaan sampai dengan,yang se

DPR, \& Presiden. Undang-Undang Republik Indonesia Nomor 21 Tahun 2008 Tentang Perbankan Syariah. , (2008).

Fatimah, S. B., \& Hendratmi, A. (2020). Digitalisasi Pada Bank Mandiri Syariah Di Tengah Persaingan Dan Perubahan Teknologi. Jurnal Ekonomi Syariah Teori Dan Terapan, 7(4), 795. https://doi.org/10.20473/vol7iss20204pp79 5-813

Hrp, A. P., \& Saraswati, D. (2020). Bank Dan Lembaga Keuangan Lainnya. Surabaya: Jakad Media Publishing.

Irawan, F. (2020). Analisis Penerapan Corporate Social Responsibility (CSR) dalam Perspektif Sharia Enterprise Theory. Minhaj: Jurnal Ilmu Syariah, 1(2).

Iskandar, A., Possumah, B. T., \& Aqbar, K. (2020). Peran Ekonomi dan Keuangan Sosial Islam saat Pandemi Covid-19.
SALAM: Jurnal Sosial Dan Budaya Syar-I, 7), 625-638. https://doi.org/10.15408/sjsbs.v7i7.15544

Karim, A. A. (2004). Sejarah Pemikiran Ekonomi Islam (3rd ed.). Jakarta: PT. Raja Grafindo Persada.

Ningsih, M. R., \& Mahfudz, M. S. (2020). Dampak Pandemi Covid-19 Terhadap Manajemen Industri Perbankan Syariah: Analisis Komparatif. Point, 2(1), 1-10. https://doi.org/10.46918/point.v2i1.576

OJK. (2017). Perbankan Syariah dan Kelembagaannya. Retrieved from https://www.ojk.go.id/id/kanal/syariah/tent ang-syariah/Pages/PBS-dan-

Kelembagaan.aspx

OJK. (2020). Peraturan OJK Nomor 11/POJK.03/2020 Tentang Stimulus Perekonomian Nasional Sebagai Countercyclical Dampak Penyebaran Coronavirus Disease 2019. 2019. https://doi.org/10.1017/CBO978110741532 4.004

Presiden, \& Mensesneg. Undang-Undang Republik Indonesia Nomor 10 Tahun 1998 Tentang Perubahan Atas Undang-Undang Nomor 7 Tahun 1992 Tentang Perbankan., (1998).

Qardhawi, Y. (2005). Spektrum Zakat Dalam Membangun Ekonomi Kerakyatan. Jakarta: Zikrul Media Intelektual.

Sumarni, Y. (2020). Pandemi Covid-19 Tantangan Ekonomi dan Bisnis. Al-Intaj: Jurnal Ekonomi Dan Perbankan Syariah, 6(2).

Tahliani, H. (2020). Tantangan Perbankan Syariah Dalam Menghadapi Pandemi COVID-19. Madani Syari'ah, 3(2), 92-113.

WHO. (2020a). Archived: WHO Timeline COVID-19. Retrieved September 21, 2020, from https://www.who.int/newsroom/detail/27-04-2020-who-timeline--covid-19

WHO. (2020b). Coronavirus. Retrieved from https://www.who.int/healthtopics/coronavirus\#tab=tab_1

Yumanita, D., Pendidikan, P., Studi, D. A. N., \& Ppsk, K. (2005). Bank Syariah: Gambaran Umum. Jakarta: Pusat Pendidikan dan Studi Kebanksentralan Bank Indonesia.

Zainur. (2020). Konsep Dasar Kebutuhan Manusia Menurut Persfektif Ekonomi Islam. Jurnal An-Nahl, 9(5). 